Document downloaded from:

http://hdl.handle.net/10251/70894

This paper must be cited as:

Ozuna López, C.; Puig Gómez, CA.; García Pérez, JV.; Carcel Carrión, JA. (2014). Ultrasonically enhanced desalting of cod (Gadus morhua). Mass transport kinetics and structural changes. Food Science and Technology. 59:130-137. doi:10.1016/j.Iwt.2014.05.062.

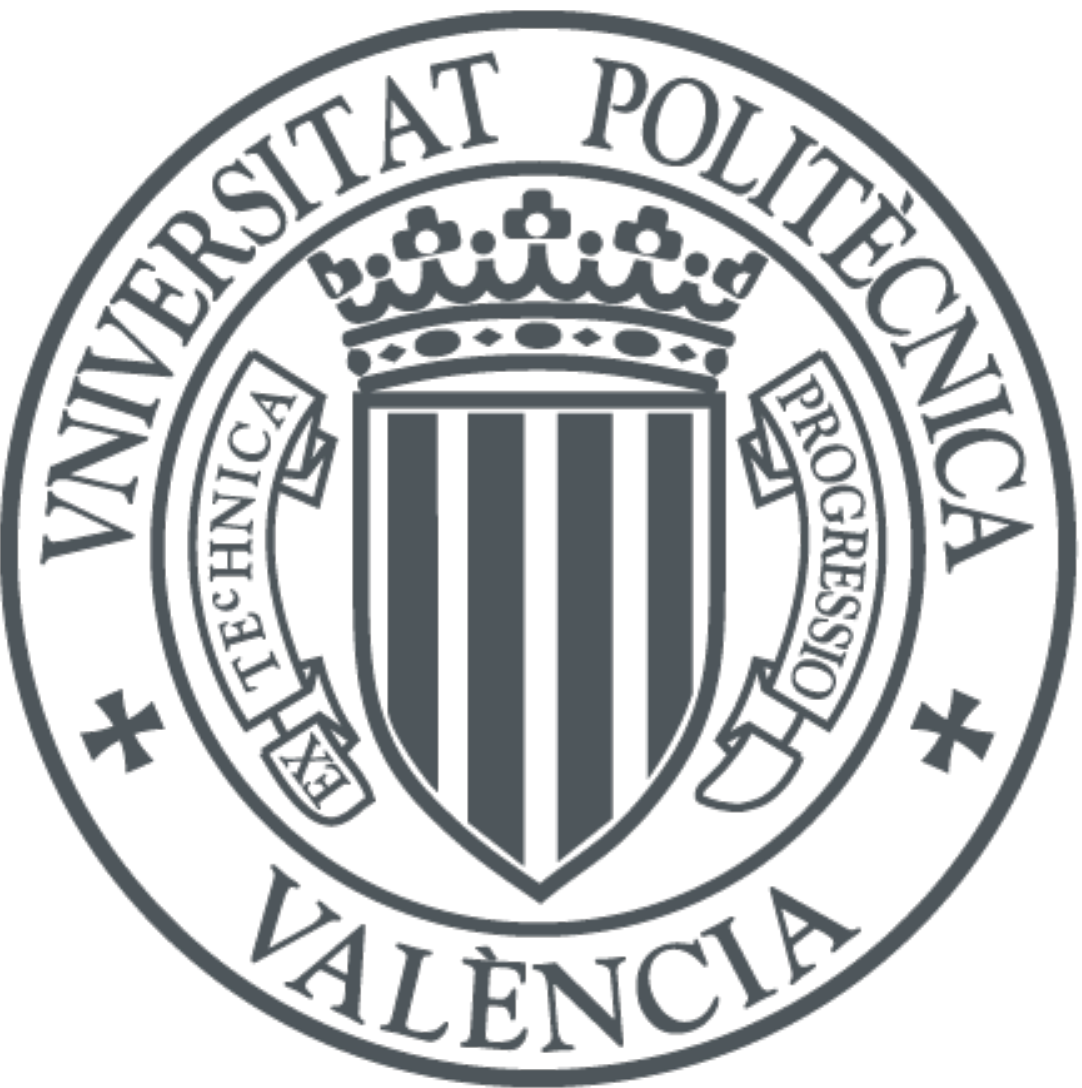

The final publication is available at

https://dx.doi.org/10.1016/j.Iwt.2014.05.062

Copyright Elsevier

Additional Information 


\section{Ultrasonically Enhanced Desalting of Cod (Gadus morhua). Mass Transport Kinetics and Structural Changes}

*Corresponding author.

Juan A. Cárcel.

1 Grupo de Análisis y Simulación de Procesos Agroalimentarios. Departamento de

22 Tecnología de Alimentos. Universitat Politècnica de València.

23 Camino de Vera. s/n. E46022. Valencia, Spain

24 Tel.: +349638793 65; Fax: +34963879839

25 E-mail address: jcarcel@tal.upv.es. 


\section{ABSTRACT}

28

The search for an alternative means of reconstituting dried and salted products prior to consumption is of relevance for the food industry. New techniques should speed up the process while causing minimum impact on product quality. Thereby, the aim of this work was to evaluate both the effect of high-intensity ultrasound application on the desalting kinetics of cod, as well as the changes in its textural and microstructural properties. Moisture and $\mathrm{NaCl}$ transport was studied separately by taking the diffusion theory into account. The evolution in the swelling and hardness of cod during desalting was determined and modeled by assuming first-order kinetics. A microstructural analysis of raw salted and desalted cod was also carried out by means of light microscopy and SEM techniques. Ultrasound application significantly $(\mathrm{p}<0.05)$ affected both moisture and $\mathrm{NaCl}$ transport and the increase in both effective diffusivities (from $24 \%$ to $103 \%$ ) was linked to the acoustic pressure applied. The desalting process induced the swelling and the softening of the cod tissue, both of which are phenomena that are intensified by ultrasound application. From the microstructural observations, it was shown that the application of high-intensity ultrasound modified the cod structure, e.g. the increase in the fiber width.

Keywords: Ultrasound, Modeling, Diffusivity, Texture, Microscopy. 
Salted cod (Gadus morhua) is one of the most widely-consumed heavy-salted products in southern European countries and Latin America (Martínez-Alvarez \& GómezGuillén, 2013; Oliveira, Pedro, Nunes, Costa, \& Vaz-Pires, 2012). Due to the unpalatably high salt concentration in the fish muscle, cod must be desalted before consumption. This process is traditionally carried out by immersing the product in stagnant water over a period of $24-48 \mathrm{~h}$. Thus, desalting is accomplished not only through the loss of salt but also as a result of sample rehydration (Barat, RodríguezBarona, Andrés \& Visquert, 2004). The combined effect of water gain and salt loss on the protein matrix (Thorarinsdottir et al., 2011) modifies the structure of product. Protein rehydration involves a loss of firmness (Barat et al., 2004). Moreover, the reduction in $\mathrm{NaCl}$ content improves the water holding capacity, which, in turn, increases the water absorption, thus contributing to the total weight gain (Oliveira et al., 2012). The main problems of industry-scale cod desalting are linked to the final product quality and long processing times. For this reason, recent research has focused on finding new cod desalting methods in order to improve the mass transfer process, like tumbling technology (Bjørkevoll, Olsen, \& Olsen, 2004), vacuum pulses (Andrés, RodríguezBarona, and Barat, 2005) or high pressures (Salvador, Saraiva, Fidalgo and Delgadillo, 2013).

67 High-intensity ultrasound (US) is being used as a novel food process intensification 68 technique (Chemat, Zill-e-Huma, \& Khan, 2011; Pananun, Montalbo-Lomboy, Noomhorm, Grewell, \& Lamsal, 2012). In liquid media, US enhances mass transfer mainly by inducing cavitation (Ozuna, Puig, García-Pérez, Mulet, \& Cárcel, 2013). In 
72 Benedito, Rosselló, \& Mulet, 2007a), the generation of microchannels in the solid or microstirring at the solid-liquid interfaces, could also affect both the external and internal mass transfer resistance (Fernandes, Gallão, \& Rodrigues, 2008). Moreover, the mechanical stress that US causes in the product may modify both structural and textural properties (Gabaldón-Leyva et al., 2007; Stadnik, Dolatowski, \& Baranowska, 2008). The effectiveness of applying US is directly linked to the actual acoustic energy introduced in the medium (Kulkarni \& Rathod, 2014). This fact mainly depends on the emitter-liquid-product coupling, which should be experimentally determined in each specific application (Cárcel, Benedito, Bon, \& Mulet, 2007b).

US has been used to enhance mass transport in the treatments of solids in hypertonic solutions, such as meat or cheese brining (Ozuna et al., 2013; Siró et al., 2009; Cárcel et al., 2007b; Sanchez et al., 1999). However, as far as we are concerned, there is no previous literature on the use of US to improve the desalting of foodstuffs. Therefore, the aim of this work was to evaluate the feasibility of using US in cod desalting from the study of the mass transport kinetics, texture evolution and microstructure of desalted samples.

\section{Materials and Methods}

2.1 Raw material and sample preparation

Salted cod (Gadus morhua) pieces $(1.50 \pm 0.25 \mathrm{~kg})$ were provided by a local supplier (Carmen Cambra S. L., Spain) to ensure the homogeneity of the raw material. Parallelepiped-shaped samples (length $50 \mathrm{x}$ width $30 \mathrm{x}$ thickness $5 \mathrm{~mm}$ ) were obtained from the central part of the cod loin using a sharp knife, wrapped in plastic waterproof film and kept refrigerated at $2 \pm 0.5^{\circ} \mathrm{C}$ (maximum storage time $120 \mathrm{~h}$ ) until the desalting experiments. 
97 The desalting treatments were carried out in an ultrasonic bath $(71 \mathrm{~L}, 40 \mathrm{kHz}$; ATU Ultrasonidos, Spain), equipped with a cooling jacket (Fig. 1F). The equipment allows the applied ultrasonic power to be modulated (up to $1500 \mathrm{~W}$ ) (Fig. 1L). For the temperature control, a glycol solution was pumped (1-38023 CLES, EBARA, Italy) (Fig. 1D) from a reservoir tank (Fig. 1E) into the cooling jacket. Afterwards, the glycol solution was cooled down in a plate heat exchanger connected to a chiller unit

\subsection{Characterization of the acoustic field}

107

Two different techniques were used to estimate the actual ultrasonic energy applied: calorimetry and acoustic pressure determination. The measurements were carried out at erosion planes produced by cavitation on a piece of aluminum foil.

112 The calorimetric method consisted of recording the temperature at 7 different points 113 (Fig. 1H) for the first 1 min of US application (Cárcel et al., 2007b). At least five Inc., USA). The output voltage level (average of 100 signal acquisitions) was converted 
$140 \quad \mathrm{TR}=\frac{\mathrm{T}}{\mathrm{T}_{0}}$

141 Hardness $(\mathrm{H})$, characterized as the maximum penetration force, was also evaluated in desalted cod samples at different times using a Texture Analyzer (TAX-T2 ${ }^{\circledR}$, Stable 
143 Micro System, United Kingdom). Penetration tests were conducted with a $2 \mathrm{~mm}$ flat 144 cylinder probe (SMS $\mathrm{P} / 2 \mathrm{~N}$ ), at a crosshead speed of $1 \mathrm{~mm} / \mathrm{s}$ and a strain of $70 \%$ 145 (penetration distance $3.5 \mathrm{~mm}$ ). In each cod sample, a preset pattern was followed in 146 order to carry out penetration tests at, at least, 12 different points.

2.5.1 Moisture and $\mathrm{NaCl}$ transport

149 A simple mathematical model based on Fick's 2nd law (Crank, 1975) was used as a first approach (Carcel et al., 2007a; Garau, Simal, Femenia \&, Rosselló, 2006) to describe the evolution of moisture and $\mathrm{NaCl}$ content in the samples during desalting. Mass transport was considered to be one-dimensional due to the fact that thickness $(5 \mathrm{~mm})$ was $1 / 6(30 \mathrm{~mm})$ and $1 / 10(50 \mathrm{~mm})$ shorter than the other dimensions. The mass flow in the thickness direction being much larger compared to the other ones due to the relative mass transfer resistances (Singh \& Heldman, 2001). Thus, approaching the slices as infinite slabs sounds reasonable (Garau et al. 2006). Constant effective diffusivities $\left(\mathrm{D}_{\mathrm{NaCl}}\right.$ and $\left.\mathrm{D}_{\mathrm{W}}\right)$, negligible changes in temperature and sample volume, solid symmetry, homogeneous initial $\mathrm{NaCl}$ and moisture contents and negligible external resistance were assumed. Eqs. 2 and 3 show the solution of the diffusion model in terms of the average moisture and $\mathrm{NaCl}$ content, respectively (Ozuna et al., 2013).

$$
\mathrm{W}=\mathrm{W}_{\mathrm{eq}}+\left(\mathrm{W}_{0}-\mathrm{W}_{\mathrm{eq}}\right)\left[2 \sum_{\mathrm{n}=0}^{\infty} \frac{1}{\lambda_{\mathrm{n}}^{2} \mathrm{~L}^{2}} \mathrm{e}^{-\mathrm{D}_{\mathrm{w}} \lambda_{\mathrm{n}}^{2} \mathrm{t}}\right]
$$

$$
\mathrm{NaCl}=\mathrm{NaCl}_{\mathrm{eq}}+\left(\mathrm{NaCl}_{0}-\mathrm{NaCl}_{\mathrm{eq}}\right)\left[2 \sum_{\mathrm{n}=0}^{\infty} \frac{1}{\lambda_{\mathrm{n}}^{2} \mathrm{~L}^{2}} \mathrm{e}^{-\mathrm{D}_{\mathrm{NaCl}} \lambda_{\mathrm{n}}^{2} \mathrm{t}}\right]
$$


163 where, $\lambda_{n}$ are the eigenvalues that are calculated by $\lambda_{n} L=(2 n+1) \frac{\pi}{2}$. In these 164 conditions and from a theoretical point of view, the effective diffusivity was considered 165 to be the only kinetic parameter that involved all the effects which influenced the 166 moisture or $\mathrm{NaCl}$ transport rate. However, in practice the effective diffusivity identified 167 by fitting the model to the experimental data included all unknown mechanisms that 168 affected the mass transfer kinetics (external resistance, sample swelling, etc.).

\subsubsection{Evolution of hardness and swelling}

170 First-order reaction models, widely used to describe the kinetics of structural changes in processed foods (Blasco, Esteve, Frígola, \& Rodrigo, 2004; Baik \& Mittal, 2003), were considered to study the evolution of the thickness ratio (Eq. 4) and hardness (Eq. 5) during desalting.

$174 \quad \mathrm{TR}=\mathrm{TR}_{\mathrm{eq}}+\left(\mathrm{TR}_{0}-\mathrm{TR}_{\mathrm{eq}}\right) \mathrm{e}^{\left(-\mathrm{k}_{\mathrm{TR}} \cdot \mathrm{t}\right)}$

$$
\mathrm{H}=\mathrm{H}_{\mathrm{eq}}+\left(\mathrm{H}_{0}-\mathrm{H}_{\mathrm{eq}}\right) \mathrm{e}^{\left(-\mathrm{k}_{\mathrm{H}} \cdot \mathrm{t}\right)}
$$

\subsection{Model fitting}

177 The parametric identification of the first order kinetics $\left(\mathrm{k}_{\mathrm{TR}}, \mathrm{TR}\right.$ eq, $\mathrm{k}_{\mathrm{H}}$ and $\left.\mathrm{H}_{\mathrm{eq}}\right)$ and the 178 diffusion models $\left(\mathrm{D}_{\mathrm{NaCl}}, \mathrm{D}_{\mathrm{W}}\right)$ was carried out by using an optimization procedure 179 (Generalized Reduced Gradient) that minimized the sum of the squared differences 180 between the experimental and calculated data. The goodness of the fit was determined by assessing the percentage of explained variance, VAR (\%) (Eq. 6).

$182 \operatorname{VAR}(\%)=\left[1-\frac{\mathrm{S}_{\mathrm{xy}}^{2}}{\mathrm{~S}_{\mathrm{y}}^{2}}\right] \cdot 100$ 
2.7.1 Scanning electron microscopy with combined dispersion X-ray analysis (SEM-EDX).

Cubic samples (side $3 \mathrm{~mm}$ ) of salted and desalted cod (CONTROL, US-750 and US1500 after 180 min of desalting) were immersed in liquid nitrogen and then freeze-dried at $1 \mathrm{~Pa}$ for 3 days (LIOALFA-6, Telstar, Spain). Then the samples were vacuum sealed in vials in the same freeze-drier so that they would remain stable (Hernando, Llorca, Puig, \& Lluch, 2011). After that, they were individually placed on SEM slides with the aid of colloidal silver and then gold-coated with carbon (SCD005, Baltec, Germany) at $10^{-2} \mathrm{~Pa}$ and an ionization current of $40 \mathrm{~mA}$. The samples were observed through a scanning electron microscope (JSM-5410, Jeol, Japan) equipped with an X-ray detector and LINK data-processing system (INCA 4.09, Oxford Instruments, England) at an acceleration voltage of $10-20 \mathrm{kV}$, which provides internal information about the standards of the energy dispersive X-ray spectra of the elements analyzed, $\mathrm{Na}^{+}$and $\mathrm{Cl}^{-}$ (Ozuna et al., 2013). For the EDX (energy-dispersive X-ray) analysis, the samples were carbon-coated (CEA035, Baltec, Germany). Mapping images of the $\mathrm{Cl}^{-}$and $\mathrm{Na}^{+}$ distribution in cod samples were taken using a voltage of $20 \mathrm{kV}$ and at a working distance of $15 \mathrm{~mm}$.

\subsubsection{Light microscopy (LM)}

202

For LM observation, cryostat sections $(200 \mu \mathrm{m})$ were obtained from frozen desalted cod (CONTROL, US-750 and US-1500 after $180 \mathrm{~min}$ of desalting) using a CM1950 microtome (Leica Biosystems, Germany). The sections were transferred to coated glass slides, which had previously been placed inside the cryo chamber to achieve an improved adherence of the tissue sections (Thorarinsdottir et al., 2011). The cryostat section samples were examined under a light microscope (Nikon Eclipse E800, Japan). 
The fiber thickness was measured from micrographs obtained by both light microscopy and SEM-EDX using the ImageJ 1.44d software (Wayne Rasband, National Institute of Health, USA). All the measurements were assessed from at least six randomly acquired images.

\section{Results and Discussion}

3.1 Acoustic field characterization

The acoustic field characterization was carried out at the two different levels of electric power used in the ultrasonically assisted desalting experiments: $750 \mathrm{~W}$ (US-750) and $1500 \mathrm{~W}$ (US-1500).

From the calorimetric measurements, it could be observed that the average volumetric energy available in the medium was $19 \pm 5 \mathrm{~kW} / \mathrm{m}^{3}$ and $37.9 \pm 5.2 \mathrm{~kW} / \mathrm{m}^{3}$ for US-750 and US-1500, respectively. The calorimetric/electric yields were close to $70 \%$.

The acoustic pressure measurements showed a very irregular acoustic field distribution in the bath (Figs. 2A and 2B): the acoustic field pattern for US-750 was different from that for US-1500. The reflections of ultrasonic waves at the moving air-water interface or the bath walls and the implosions of cavitation bubbles (Kulkarni \& Rathod, 2014) can generate this heterogeneous ultrasonic field. As regards the integrated average acoustic pressure, it was $0.5 \pm 0.1$ bar (Fig. 2B; range $0.3-0.8$ bar) for US-1500, but 0.4 \pm 0.1 bar (Fig. 2A; range 0.1-0.7 bar) for US-750.

As can be observed, doubling the electric energy supplied to the bath transducers doubles the energy measured by calorimetry but not that measured using the hydrophone.

The calorimetric method measured the thermal effects produced by US, while acoustic pressure is a measurement of only mechanical effects. The interaction between waves 
produced by reflections or cavitation can partially neutralize them producing a conversion of acoustic energy into heat. Therefore, acoustic pressure is a more accurate measurement of the ultrasonic mechanical energy available to produce effects.

\subsection{Mass transport}

\subsubsection{Experimental $\mathrm{NaCl}$ and water content}

Salted cod loin showed an initial $\mathrm{NaCl}$ content of $0.6 \pm 0.2 \mathrm{~kg} \mathrm{NaCl} / \mathrm{kg}$ SFS (salt-free solids). The immersion of samples in water produced a decrease in $\mathrm{NaCl}$ content, which was greater when US was applied (Fig. 3A). Thus, after 180 min of desalting, the $\mathrm{NaCl}$ content in US-1500 $(0.114 \pm 0.007 \mathrm{~kg} \mathrm{NaCl} / \mathrm{kg} \mathrm{SFS})$ was $32 \%$ lower than that measured in CONTROL samples $(0.17 \pm 0.03 \mathrm{~kg} \mathrm{NaCl} / \mathrm{kg} \mathrm{SFS})$. US-750 showed an intermediate $\mathrm{NaCl}$ content $(0.13 \pm 0.04 \mathrm{~kg} \mathrm{NaCl} / \mathrm{kg} \mathrm{SFS})$. Therefore, the influence of US depended on the acoustic power applied (Fig. 3A).

As regards the moisture content, the cod loin's initial content of $1.9 \pm 0.2 \mathrm{~kg}$ water $/ \mathrm{kg}$ SFS increased during the experiments. The US application also significantly $(p<0.05)$ accelerated the water transport (Fig. 3B). For example, the moisture content of CONTROL after 180 min of treatment ( $3.0 \pm 0.4 \mathrm{~kg}$ water $/ \mathrm{kg}$ SFS) was achieved for US1500 in only $63 \mathrm{~min}(65 \%$ reduction in treatment time). As in the case of $\mathrm{NaCl}$ transport, the water gain was dependent on the acoustic power applied.

\subsubsection{Modeling transport kinetics}

The fit of the proposed diffusion models to the experimental data provided percentages of explained variance ranging from 93 to $95 \%$ for $\mathrm{NaCl}$ and 95 to $97 \%$ for moisture kinetics (Table 1). These low values can be attributed to the great variability of the raw material (Oliveira et al., 2012; Barat et al., 2004). However, the trend between 
calculated and experimental data was quite similar (Fig. 3), showing the feasibility of the model.

257 The $\mathrm{D}_{\mathrm{NaCl}}$ values identified for CONTROL $\left(4.57 \times 10^{-10} \mathrm{~m}^{2} / \mathrm{s}\right)$ were in the same order of magnitude as others found in literature (Barat et al., 2006 and 2004) for cod desalting.

259 The application of US during desalting produced a significant $(p<0.05)$ increase in $\mathrm{D}_{\mathrm{NaCl}}$, which depended on the power applied. Thus, $\mathrm{D}_{\mathrm{NaCl}}$ was $25 \%$ higher for US-750 and $62 \%$ higher for US-1500 than the figure identified for CONTROL experiments (Table 1). The relationship between the applied acoustic energy and the identified $\mathrm{D}_{\mathrm{NaCl}}$ was better described from acoustic pressure measurements than from calorimetric. Between the US-750 and US-1500 experiments there was observed to be a $30 \%$ increase in acoustic pressure (from 0.39 bar to 0.51 bar, respectively) and this provided a close fit to the $30 \%$ increase in the identified $\mathrm{D}_{\mathrm{NaCl}}$ (Table 1), while using calorimetry, an effective diffusivity increase of $103 \%$ would be expected. During the desalting experiments, the temperature was held at $4{ }^{\circ} \mathrm{C}$ and, as a result, only ultrasonic mechanical effects on mass transport took place, which are well quantified from the acoustic pressure measurement. Calorimetric measurements, on the other hand, are more suitable for quantifying the thermal effects produced by ultrasound. In the case of moisture transport, the increase in $\mathrm{D}_{\mathrm{w}}$ brought about by US application was close to $41 \%$ for US-750 and $103 \%$ for US-1500 as compared to CONTROL experiments. As in the case of $\mathrm{D}_{\mathrm{NaCl}}$, the increase in $\mathrm{D}_{\mathrm{W}}$ was also well correlated with

275 the increase in acoustic pressure.

276 The increase in solute and moisture transport when applying ultrasound has been

277 previously described in other solid-liquid systems. Thus, Siró et al. (2009) found increases of $96 \%$ in $\mathrm{D}_{\mathrm{NaCl}}$ when US was applied during meat brining $\left(5^{\circ} \mathrm{C}, 4 \% \mathrm{NaCl}\right)$, 
and Gabaldón-Leyva et al. (2007) observed an improvement of 190\% in the total solid diffusion coefficients during the brining of bell pepper $\left(55^{\circ} \mathrm{C}, 13.51 \% \mathrm{NaCl}\right)$. Ozuna et al. (2013) reported increases in Dw of around $101 \%$ when US was applied in meat brining $\left(5^{\circ} \mathrm{C}, 28 \% \mathrm{NaCl}\right)$ and Cárcel et al. (2007a) found increases of $117 \%$ in moisture transport during the osmotic dehydration of apple $\left(30^{\circ} \mathrm{C}, 30^{\circ} \mathrm{Brix}\right)$.

It should be pointed out that, even the proposed theoretical model considers the moisture and $\mathrm{NaCl}$ transport only controlled by diffusion, the effective diffusivities ( $\mathrm{D}_{\mathrm{NaCl}}$ and $\mathrm{D}_{\mathrm{W}}$ ) identified are just kinetic parameters, which also include other phenomena affecting the mass transport, such as external convective flow or volume sample changes (Mulet, 1994) like swelling. The influence of US on mass transport comes from the appearance of effects such as the so-called "sponge effect" or the generation of microchannels (Cárcel et al., 2010) that reduce the internal resistance and the generation of microstirring or the implosion of cavitation bubbles at interfaces that enhance the external mass transport (Chemat et al., 2011). As previously explained, temperature control avoids any improvement linked to thermal energy.

\subsection{Evolution of swelling}

The application of US during desalting increased the swelling, measured from the TR (Eq. 1), and this increase depended on the level of acoustic power applied (Fig. 4A). Thus, after 180 min desalting, while US-750 samples showed a TR value $(2.8 \pm 0.1)$ which was $22 \%$ higher than that of CONTROL $(2.3 \pm 0.4)$, in the case of US-1500 there was a $50 \%$ increase $(3.4 \pm 0.3)$.

As for the experimental variability, the first order kinetic (Eq. 4) provided an adequate estimation of the TR (Table 2). The rate constant ( $\left.\mathrm{k}_{\mathrm{TR}}\right)$, which is related with the rate of swelling during desalting, was not significantly $(\mathrm{p}<0.05)$ increased by US application 
(Table 2). As can be observed in Fig. 4B, there was no direct kinetic effect on the swelling itself produced by US, but the influence observed on the experimentally measured swelling can be simply linked to the fact that US application intensified water transport.

\subsection{Evolution of hardness}

The measurements of the maximum penetration force showed that the initial degree of hardness of the salted cod $(3.6 \pm 0.4 \mathrm{~N})$ reduced as the desalting process progressed (Fig. 5). Major hardness changes took place in the first $45 \mathrm{~min}$ and an asymptotic value was found after approximately $60 \mathrm{~min}$ of desalting (Fig. 5A). US application accelerated this reduction in hardness (Fig. 5A), with the greatest differences between CONTROL and US experiments observed at the beginning of the desalting. Unlike what was observed in the case of swelling, the influence of US on the evolution of hardness can be attributed not only to the ultrasonic intensification of mass transport but also to some textural effects (Stadnik et al., 2008), since, at a similar water content, US samples exhibited a lower hardness value than CONTROL (Fig. 5B). No differences were observed between US-750 and US-1500.

The ability of US to induce structural effects has already been reported (GabaldónLeyva et al. 2007; Ozuna et al., 2013). The compressions and expansions produced by US induced mechanical stress on both the protein structure and the constituents of the connective tissue that can lead to softening.

The first-order kinetic model (Eq. 5) accurately described the hardness changes during desalting (Fig. 5A). Both model parameters $\left(\mathrm{k}_{\mathrm{H}}\right.$ and $\left.\mathrm{H}_{\mathrm{eq}}\right)$ were significantly $(\mathrm{p}<0.05)$ affected by US application. However, no significant differences were found between the two acoustic powers tested (Table 2$)$. The rate constant $\left(\mathrm{K}_{H}\right)$ significantly $(\mathrm{p}<0.05)$ 
increased when acoustic energy was applied as indicated by the more marked reduction in hardness when US was applied (Fig. 5B). The equilibrium hardness value $\left(\mathrm{H}_{\mathrm{eq}}\right)$ was lower for US treatments than CONTROL, which may be ascribed to the abovementioned structural effects of US.

\subsection{Microstructure}

SEM micrographs showed the microstructure of salted cod (Fig. 6). The cod fibers, covered by salt deposits (Fig. 6A), presented an intense dehydration and compaction with a total degradation of connective tissue. The high content of salt masked the underlying structures (Fig. 6B). During desalting, important changes take place as a consequence of cell rehydration. After $180 \mathrm{~min}$ of treatment, samples showed a significant swelling of muscle fibers (Figs. 7A, 7B and 7C) compared to salted cod (Fig. 6). Thus, the fibers' average width increased from $64.4 \pm 9.2 \mu \mathrm{m}$ in the case of salted cod fibers to $84.1 \pm 11.7 \mu \mathrm{m}$ in CONTROL samples. This increase was even greater when US was applied (Figs. 7B and 7C). In this sense, US-1500 fibers (Fig. 7C) were $27 \%$ wider $(106.7 \pm 11.5 \mu \mathrm{m})$ than CONTROL. This fiber width increase was also observed in LM micrographs. In this case, the measured fiber width increased from 90.4 $\pm 4.4 \mu \mathrm{m}$ in CONTROL (Fig. 7D) to $108.8 \pm 13.2$ and $139.4 \pm 11.7 \mu \mathrm{m}$ in US-750 (Fig. 7E) and US-1500 (Fig. 7F), respectively. The differences between LM and SEM measurements can be attributed to the differences in sample preparation.

The fiber width increase explains the macroscopic swelling already described in Fig. 4. In addition, the US application increased the interfibrillar spaces (IS) (Figs. 7B and 7C) that can also contribute to the softening of US samples (Fig. 5). The SEM-EDX technique confirmed that US application intensified the $\mathrm{NaCl}$ leakage (Figs. 7B and 
350 7C), which was manifested by a lower number of dots in micrographs than in 351 CONTROL (Fig. 7A).

352 The LM micrographs also showed the mechanical effects of acoustic energy. The US 353 samples presented greater fiber and connective tissue degradation (Figs. 7E and 7F) 354 than CONTROL (Fig. 7D). This fact can be attributed to violent microjets produced by 355 the asymmetric implosion of bubbles near the solid surface. These results coincide with 356 those found by other authors who related the application of US with the physical 357 disruption of the myofibril structure (Ozuna et al., 2013), the degradation of collagen 358 macromolecules, or the creation of micro-channels (Jayasooriya, Bhandari, Torley, \& 359 D'Arcy, 2004).

\section{Conclusions}

361 The application of high-intensity ultrasound improved cod desalting, increasing both moisture and $\mathrm{NaCl}$ effective diffusivities by up to 103 and $62 \%$, respectively. The desalting induced the tissue swelling and the decrease in sample hardness, both of which were intensified by ultrasound application. Microstructural analyses showed that cod fibers were significantly affected by ultrasound application. These facts not only coincide with the intensification of mass transport and the observed enhancement of swelling, but also with the decrease in hardness.

\section{Acknowledgments}

The authors acknowledge the financial support of the Spanish Ministerio de Economía y Competitividad and FEDER (Ref. DPI2013-37466-C03-03). César Ozuna thanks

371 Universitat Politècnica de València for an FPI grant (Ref. 2009-02). The author also

372 wishes to thank Carmen Cambra S.L. for selecting the raw material. 


\begin{tabular}{lll}
\hline Symbol & Reference & Unit \\
\hline $\mathrm{SFS}$ & Salt-free solids & $\mathrm{kg}$ water $/ \mathrm{kg} \mathrm{SFS}$ \\
$\mathrm{W}_{0}$ & Initial moisture content, & $\mathrm{kg}$ water $/ \mathrm{kg} \mathrm{SFS}$ \\
$\mathrm{W}_{\mathrm{eq}}$ & Equilibrium moisture content, & $\mathrm{kg} \mathrm{NaCl} / \mathrm{kg} \mathrm{SFS}$ \\
$\mathrm{NaCl}_{0}$ & Initial sodium chloride content, & $\mathrm{kg} \mathrm{NaCl} / \mathrm{kg} \mathrm{SFS}$ \\
$\mathrm{NaCl}_{\mathrm{eq}}$ & Equilibrium sodium chloride content, & $\mathrm{s}$ \\
$\mathrm{t}$ & Time, & $\mathrm{m}^{2} / \mathrm{s}$ \\
$\mathrm{D}_{\mathrm{NaCl}}$ & Effective NaCl diffusivity, & $\mathrm{m}^{2} / \mathrm{s}$ \\
$\mathrm{D}_{\mathrm{W}}$ & Effective moisture diffusivity, & $\%$ \\
$\Delta \mathrm{D}_{\mathrm{NaCl}}$ & NaCl effective diffusivity increase by ultrasound & $\%$ \\
$\Delta \mathrm{D}_{\mathrm{w}}$ & Effective moisture diffusivity increase by ultrasound & $\%$ \\
$\mathrm{~L}$ & Half length, & $\mathrm{m}$ \\
$\lambda_{\mathrm{n}}$ & Eigenvalues & \\
$\mathrm{T}_{0}$ & Initial sample thickness, & $\mathrm{m}$ \\
$\mathrm{T}$ & Thickness after a certain time of treatment & $\mathrm{m}$ \\
$\mathrm{TR}_{0}$ & Initial thickness ratio & \\
$\mathrm{TR}_{\mathrm{eq}}$ & Equilibrium thickness ratio & $\mathrm{N}$ \\
$\mathrm{H}_{0}$ & Initial hardness, & $\mathrm{N}$ \\
$\mathrm{H}_{\mathrm{eq}}$ & Equilibrium hardness, & $1 / \mathrm{s}$ \\
$\mathrm{k}_{\mathrm{TR}}$ & Rate constant of thickness ratio, & $\mathrm{N} / \mathrm{s}$ \\
$\mathrm{k}_{\mathrm{H}}$ & Rate constant of hardness, & \\
$\mathrm{S}_{\mathrm{y}}$ & Standard deviation of the sample & \\
$\mathrm{S}_{\mathrm{yx}}$ & Standard deviation of the estimation & \\
\hline
\end{tabular}




\section{References}

Andrés, A., Rodríguez-Barona, S., \& Barat, J.M. (2005). Analysis of some coddesalting process variables. Journal of Food Engineering, 70, 67-72.

Association of Official Analytical Chemists. Official Methods of Analysis; AOAC: Washington, DC, 1997.

Baik, O. D., \& Mittal, G. S. (2003). Kinetics of tofu color changes during deep-fat frying. LWT-Food Science and Technology, 36, 43-48.

Barat, J. M., Gallart-Jornet, L., Andrés, A., Akse, L., Carlehög, M., \& Skjerdal, O. T. (2006). Influence of cod freshness on the salting, drying and desalting stages. Journal of Food Engineering, 73, 9-19.

Barat, J.M., Rodríguez-Barona, S., Andrés, A. \& Visquert, M. (2004). Mass transfer analysis during the cod desalting process. Food Research International, 37, 203208.

Bjørkevoll, I. Olsen, J., \& Olsen, R.L. (2004). Rehydration of salt-cured cod using injection and tumbling technologies. Food Research International, 37, 925-931.

Blasco, R., Esteve, M. J., Frígola, A., \& Rodrigo, M. (2004). Ascorbic acid degradation kinetics in mushrooms in a high-temperature short-time process controlled by a thermoresistometer. LWT-Food Science and Technology, 37, 171-175.

Cárcel, J.A., Benedito, J., Rosselló, C., \& Mulet, A. (2007a). Influence of ultrasound intensity on mass transfer in apple immersed in a sucrose solution. Journal of Food Engineering, 78, 472-479.

Cárcel, J. A., Benedito, J., Bon, J., \& Mulet, A. (2007b). High intensity ultrasound effects on meat brining. Meat science, 76, 611-619. 
Cárcel, J. A., García-Pérez, J. V., Benedito, J., Mulet, A., 2012. Food process innovation through new technology: Use of ultrasound. Journal of Food Engineering, 110, 200-207.

Chemat, F., Zill-e-Huma, \& Khan, M.K. (2011). Applications of ultrasound in food technology: processing, preservation and extraction. Ultrasonics Sonochemistry, $18,813-835$.

Crank, J. (1975). The Mathematics of Diffusion. London: Oxford University Press.

Fernandes, F. A. N., Gallão, M. I., \& Rodrigues, S. (2008). Effect of osmotic dehydration and ultrasound pre-treatment on cell structure: melon dehydration. LWT-Food Science and Technology, 41, 604-610.

Gabaldón-Leyva, C. A., Quintero-Ramos, A., Barnard, J., Balandrán-Quintana, R. R., Talamás-Abbud, R., \& Jiménez-Castro, J. (2007). Effect of ultrasound on the mass transfer and physical changes in brine bell pepper at different temperature. Journal of Food Engineering, 81, 374-379.

Garau, M. C., Simal, S., Femenia, A., \& Rosselló, C. (2006). Drying of orange skin: drying kinetics modelling and functional properties. Journal of Food Engineering, 75, 288-295.

Hernando, I., Llorca, E., Puig, A. \& Lluch, M.A. (2011). Microstructure. In L.M.L., M.L. Leo \& F. Toldra (Eds.), Handbook of Seafood and Seafood Products Analysis (pp. 139-151). Boca Raton FL: CRC Press Taylor \& Francis Group.

Jayasooriya, S. D., Bhandari, B. R., Torley, P., \& D'Arcy, B. R. (2004). Effect of high power ultrasound waves on properties of meat: a review. International Journal of Food Properties, 7, 301-319. 
421 Kulkarni, V. M., \& Rathod, V. K. (2014). Mapping of an ultrasonic bath for ultrasound assisted extraction of mangiferin from Mangifera indica leaves. Ultrasonics Sonochemistry, 21, 606-611.

424

Martínez-Alvarez, O., \& Gómez-Guillén, C. (2013). Influence of mono- and divalent salts on water loss and properties of dry salted cod fillets. LWT-Food Science and Technology, 53, 387-394.

Mulet, A., 1994, Drying modelling and water diffusivity in carrots and potatoes. Journal of Food Engineering, 22, 329-348.

Oliveira, H. , Pedro S., Nunes, M. L., Costa, R., \& Vaz-Pires, P. (2012). Processing of salted cod (Gadus spp.): a review. Comprehensive Reviews in Food Science and Food Safety, 11, 546-564.

Ozuna, C., Puig, A., García-Pérez, J.V., Mulet, A., \& Cárcel, J.A. (2013). Influence of high intensity ultrasound application on mass transport, microstructure and textural properties of pork meat (Longissimus dorsi) brined at different $\mathrm{NaCl}$ concentrations. Journal of Food Engineering, 119, 84-93.

Pananun, T., Montalbo-Lomboy, M., Noomhorm, A., Grewell, D., \& Lamsal, B. (2012). High-power ultrasonication-assisted extraction of soybean isoflavones and effect of toasting. LWT-Food Science and Technology, 47, 199-207.

Salvador, Â. C., Saraiva, J. A., Fidalgo, L. G., \& Delgadillo, I. (2013). Effect of high pressure on cod (Gadus morhua) desalting. High Pressure Research, 33, 432439.

Sánchez, E. S., Simal, S., Femenia, A., Benedito, J., \& Rosselló, C. (1999). Influence of ultrasound on mass transport during cheese brining. European Food Research and Technology, 209, 215-219. 
445 Singh, R. P. \& Heldman, D.R. (2001). Introduction to Food Engineering. Academic Press (3rd ed.). San Diego, USA.

447 Siró, I., Vén, C., Balla, C., Jónás, G., Zeke, I., \& Friedrich, L. (2009). Application of an ultrasonic assisted curing technique for improving the diffusion of sodium chloride in porcine meat. Journal of Food Engineering, 91, 353-362.

450 Stadnik, J., Dolatowski, Z. J., \& Baranowska, H. M. (2008). Effect of ultrasound 451 treatment on water holding properties and microstructure of beef $(\mathrm{m}$. semimembranosus) during ageing. LWT-Food Science and Technology, 41, 2151-2158.

454 Thorarinsdottir, K. A., Arason, S., Sigurgisladottir, S., Gunnlaugsson, V. N. Johannsdottir, J., \& Tornberg, E. (2011). The effects of salt-curing and salting procedures on the microstructure of cod (Gadus morhua) muscle. Food Chemistry, 126, 109-115.

458 


\section{Figure captions}

Fig. 1 Desalting set-up. A) chiller B) valve C) heat exchanger D) pump E) cooling reservoir F) ultrasonic bath $G$ ) sample holder H) thermocouples I) cod samples J) ultrasonic transducers K) data logger L) ultrasonic generator M) Computer.

Fig. 2. Acoustic pressure (bar) distribution in the ultrasonic bath with an applied electric power of $750 \mathrm{~W}(\mathrm{~A})$ and $1500 \mathrm{~W}(\mathrm{~B})$ in a horizontal section at $100 \mathrm{~mm}$ from the water surface.

Fig. 3 Experimental $\mathrm{NaCl}(\mathrm{A})$ and moisture (B) transport kinetics of salted cod slices triplicate) and LSD intervals $(\mathrm{p}<0.05)$.

Fig 4. Evolution of thickness ratio vs time (A) and vs moisture content (B) during desalting of salted cod with (US, $40 \mathrm{kHz}, 750$ and $1500 \mathrm{~W}$ ) and without ultrasound application (CONTROL). Average values (each point represents the average of 8 measurements) and LSD intervals $(\mathrm{p}<0.05)$.

Fig 5. Evolution of hardness vs time (A) and vs moisture content (B) during desalting of salted-cod with (US, $40 \mathrm{kHz}, 750$ and $1500 \mathrm{~W}$ ) and without ultrasound application (CONTROL). Average values (each point represents the average of 30 measurements) and LSD intervals $(\mathrm{p}<0.05)$.

Fig 6. Longitudinal (A) and transversal (B) section of salted cod (Gadus morhua) fibers observed by SEM (x500). S: $\mathrm{NaCl}$ deposits, IS: Interfibrillar space. 
Fig 7. Longitudinal section observed by SEM-EDX (A, B and C; x500) and LM (D, E and F; $\mathrm{x} 4$ ) of cod loin desalted for 180 min without (CONTROL, A, D), and with US at $750(\mathrm{~B}, \mathrm{E})$ and $1500 \mathrm{~W}(\mathrm{C}, \mathrm{F})$. IS: Interfibrillar space.

\section{Table captions}

Table 1. Average values and confidence intervals (95\%) of effective diffusivity of moisture $\left(\mathrm{D}_{\mathrm{W}}\right)$ and $\mathrm{NaCl}\left(\mathrm{D}_{\mathrm{NaCl}}\right)$ identified from modeling of cod desalting $\left(4 \pm 1{ }^{\circ} \mathrm{C}\right)$ with (US, $40 \mathrm{kHz}, 750$ and $1500 \mathrm{~W}$ ) and without US application (CONTROL) and percentage of explained variance by the model (VAR (\%)). $\Delta \mathrm{DW}_{\mathrm{W}}$ and $\Delta \mathrm{D}_{\mathrm{NaCl}}(\%)$ are the increases in effective diffusivity produced by ultrasound application.

Table 2. First-order kinetic parameters for thickness ratio (TReq, $\left.\mathrm{K}_{\mathrm{TR}}\right)$ and evolution of hardness $\left(\mathrm{H}_{\mathrm{eq}}, \mathrm{K}_{\mathrm{H}}\right)$ during cod desalting $\left(4 \pm 1{ }^{\circ} \mathrm{C}\right)$ with (US, $40 \mathrm{kHz}, 750$ and 1500 W) and without US application (CONTROL). Average \pm confidence intervals of the estimation (95\%) are shown. 
(A)

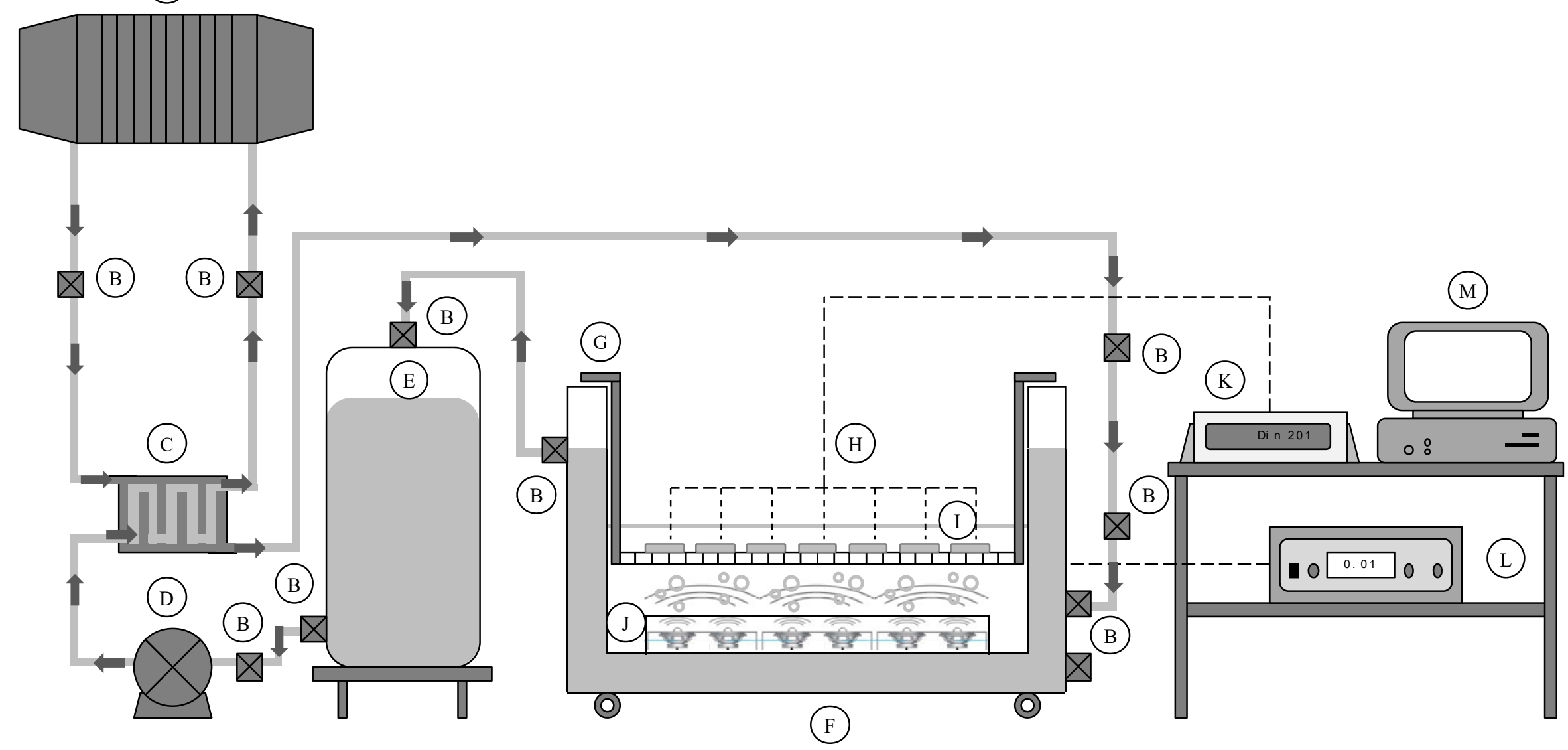

$497 \quad$ Fig 1 

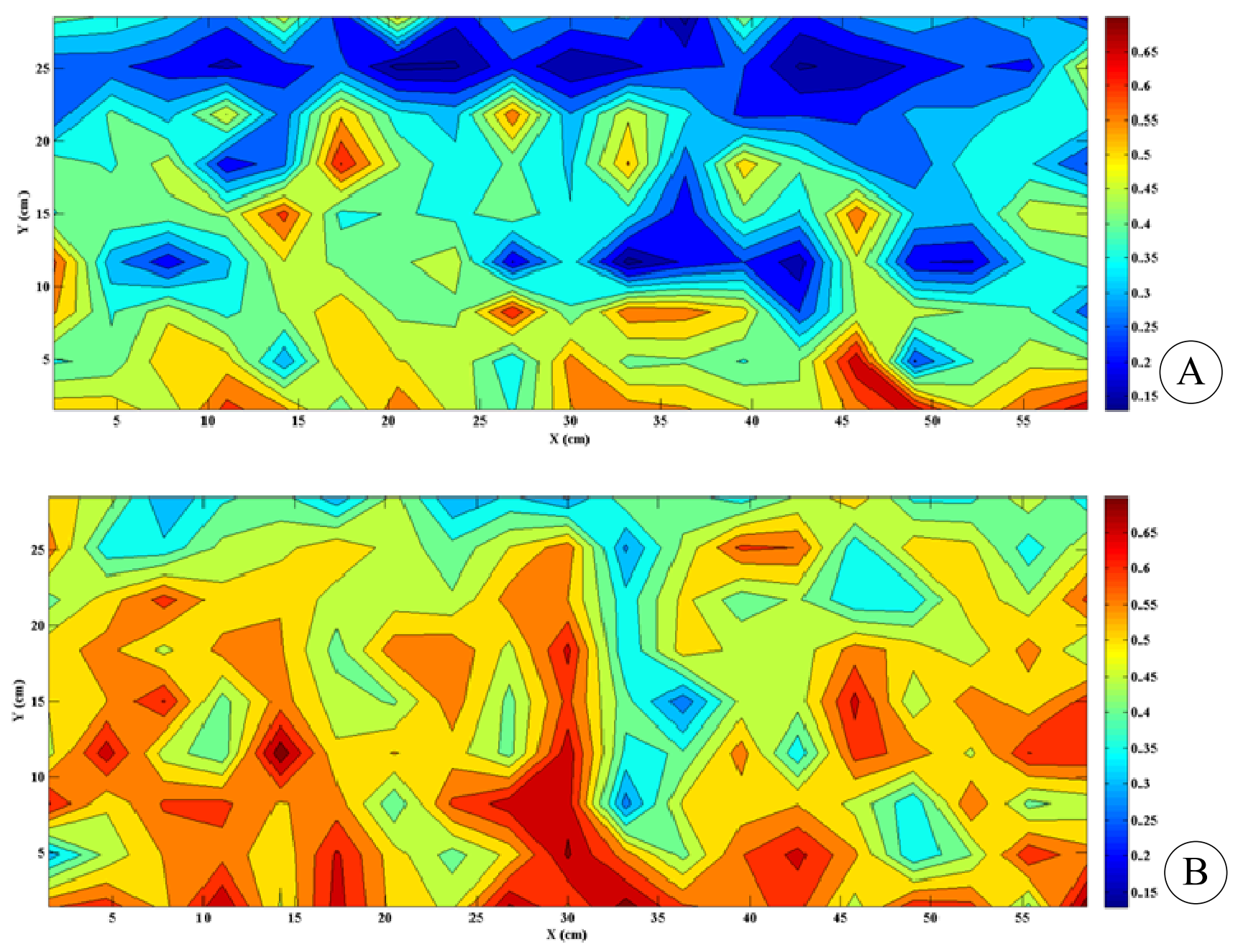

499

$500 \quad$ Fig 2 

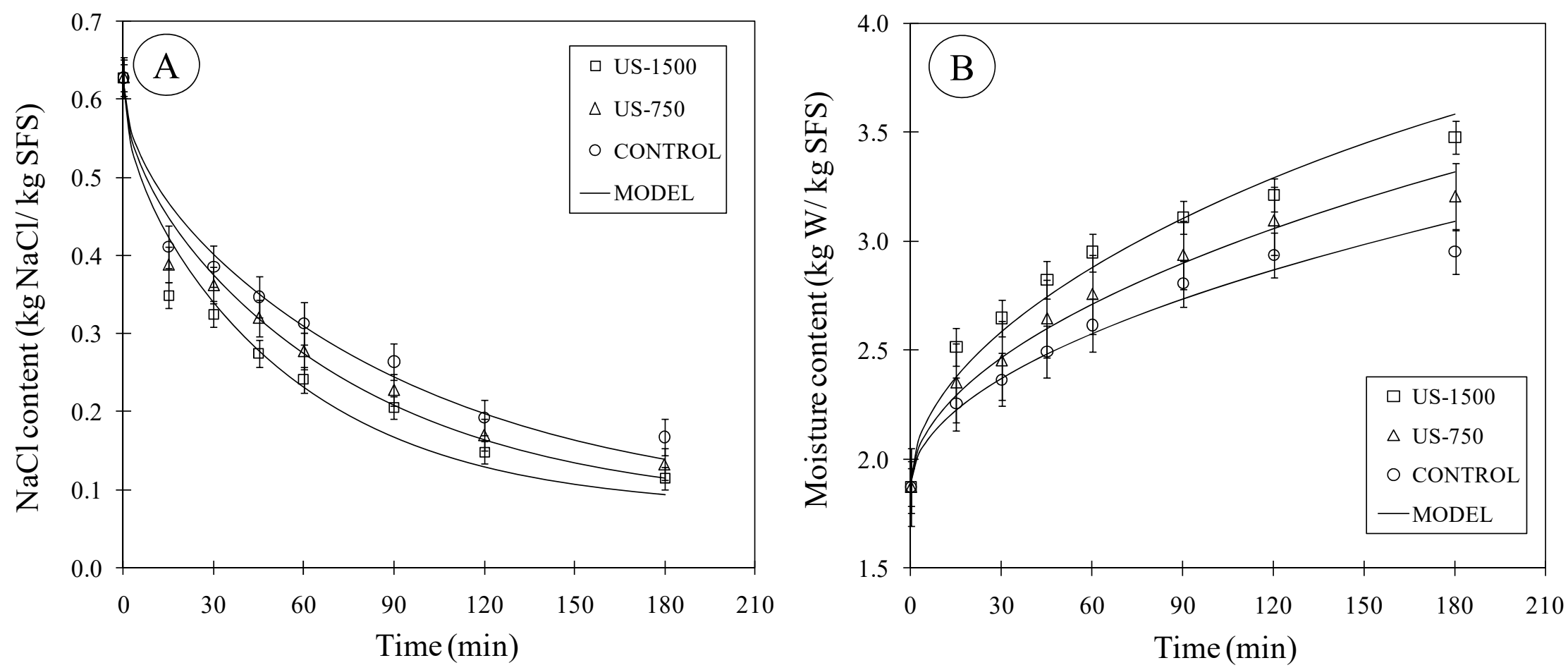

501 

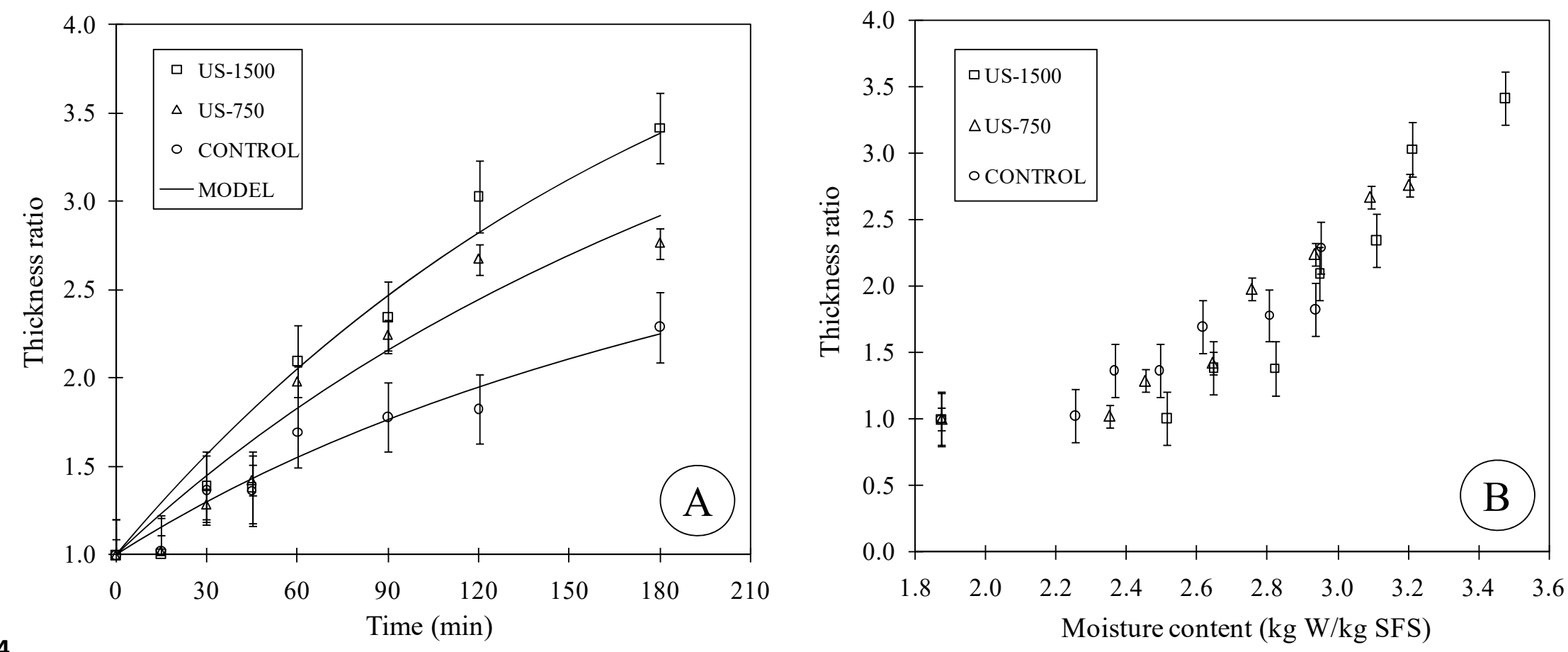

\section{$504 \quad$ Fig 4}



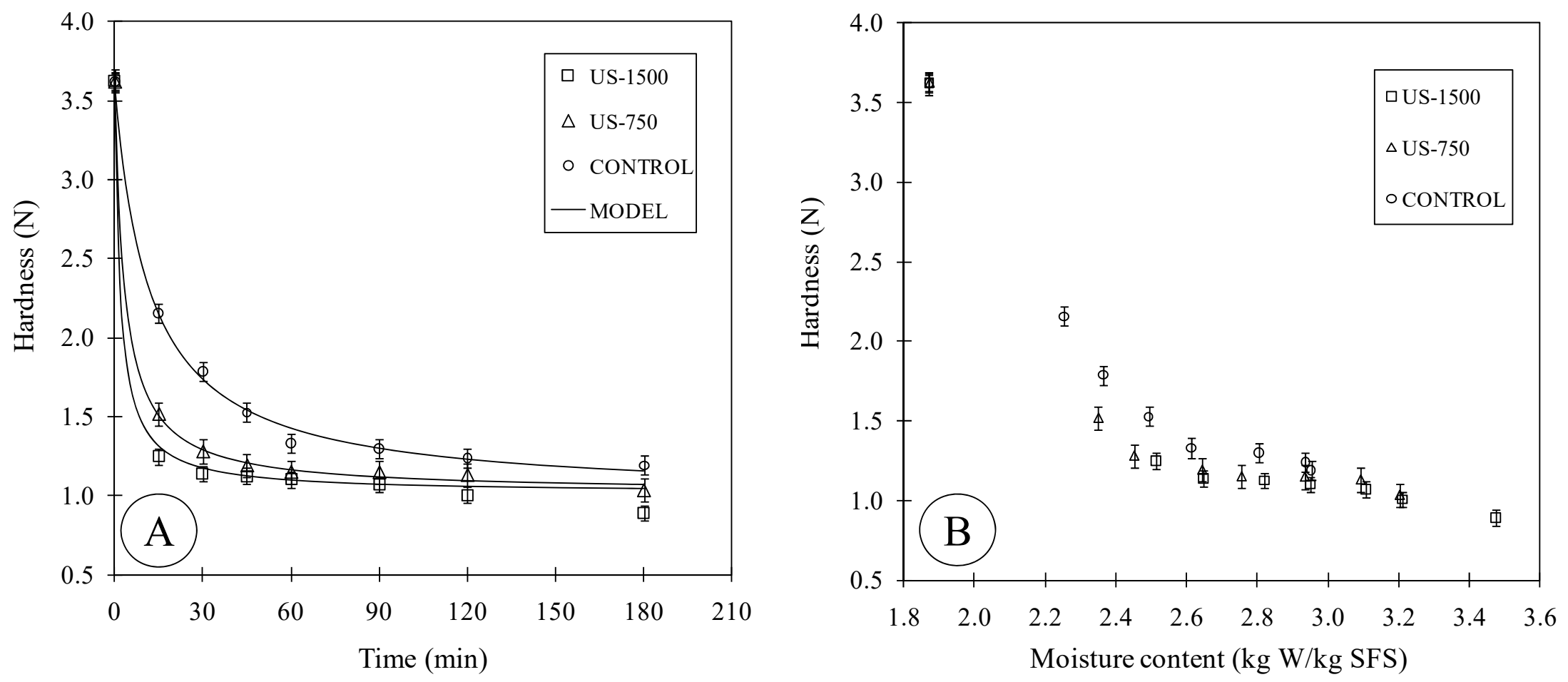

506

\section{Fig 5}



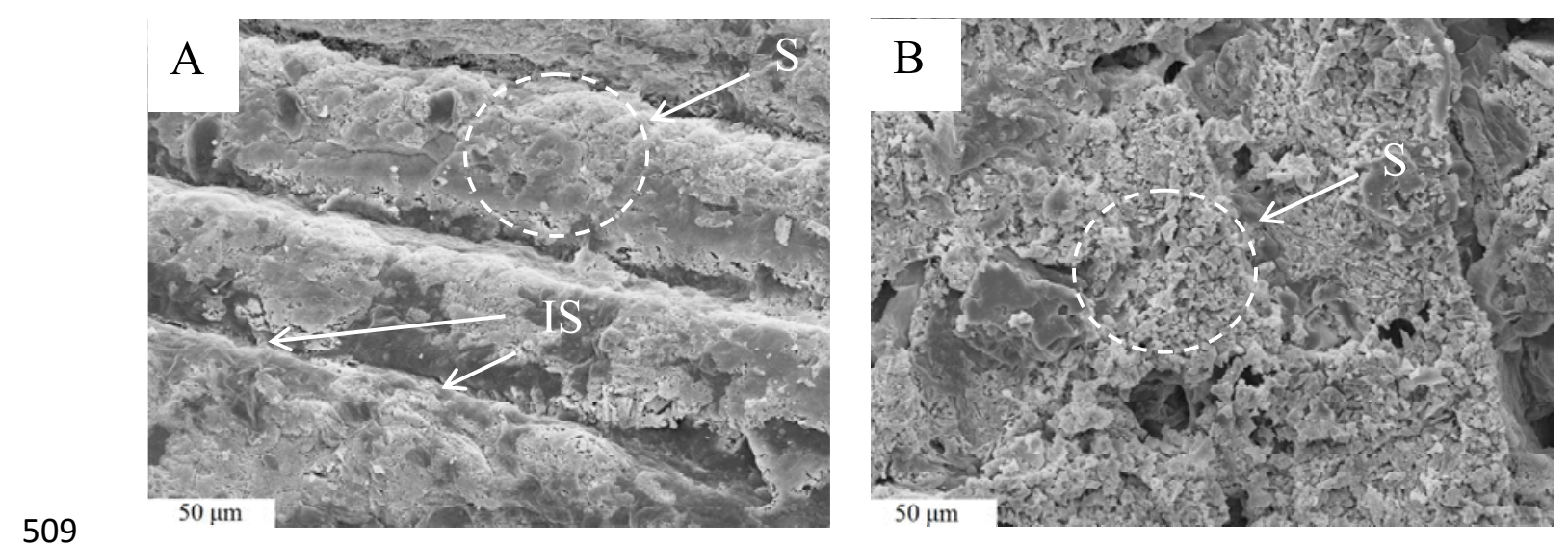

$510 \quad$ Fig 6

511 
SEM. X-ray
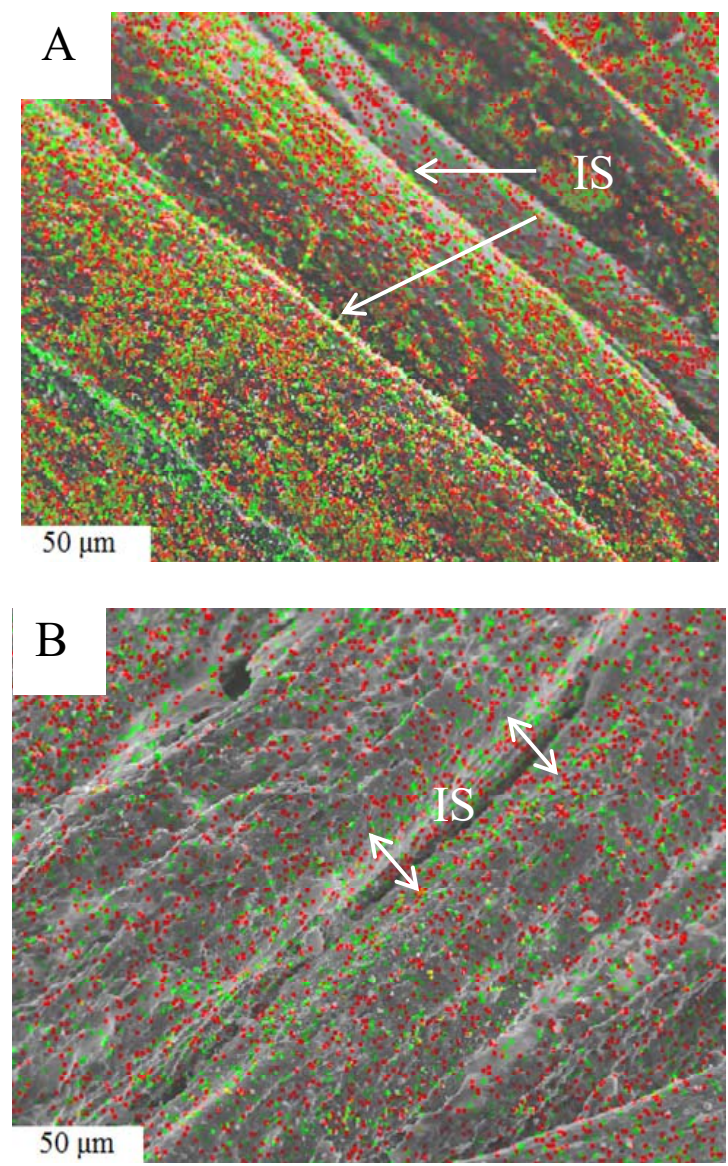

512

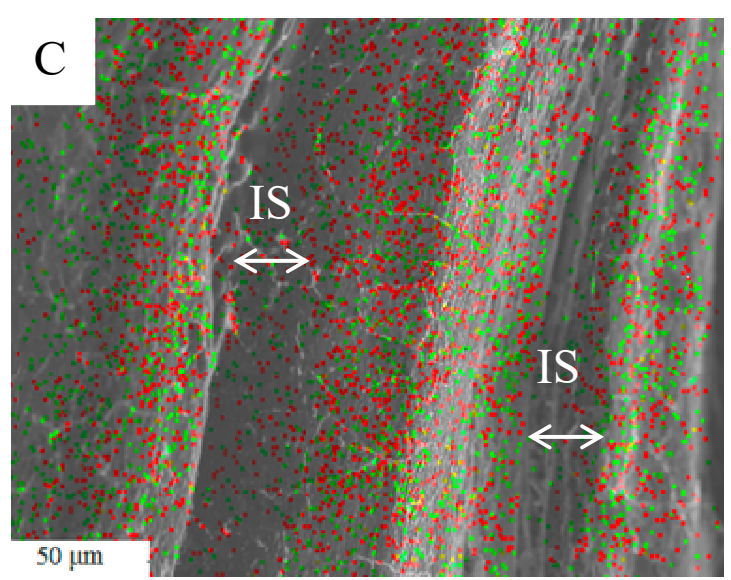

Light microscopy
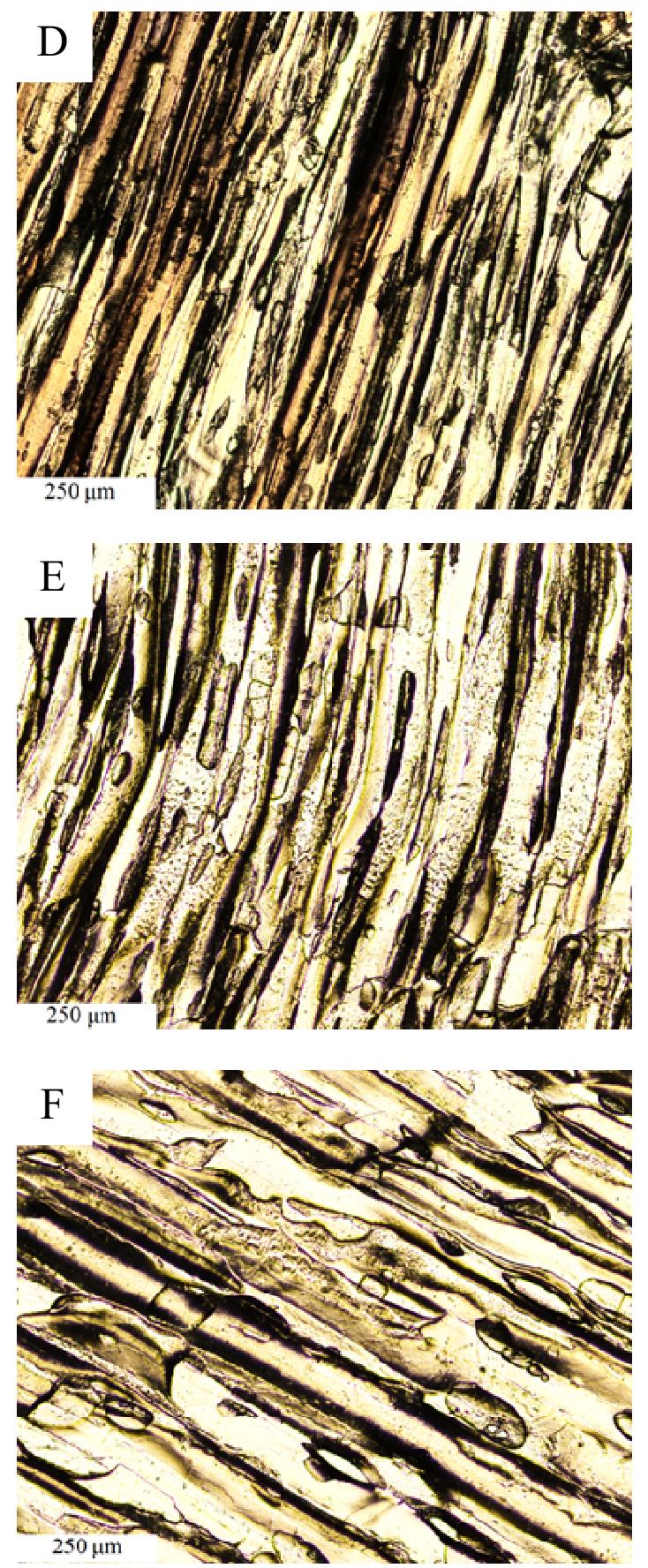

Fig. 7 
Table 1

\begin{tabular}{|c|c|c|c|c|c|c|}
\hline & \multicolumn{3}{|c|}{$\mathrm{NaCl}$ transport } & \multicolumn{3}{|c|}{ Water transport } \\
\hline & $\mathrm{D}_{\mathrm{NaCl}}\left(10^{-10}\right)\left[\mathrm{m}^{2} / \mathrm{s}\right]$ & $\Delta \mathrm{D}_{\mathrm{NaCl}}(\%)$ & VAR (\%) & $\mathrm{D}_{\mathrm{W}}\left(10^{-10}\right)\left[\mathrm{m}^{2} / \mathrm{s}\right]$ & $\Delta \mathrm{D}_{\mathrm{W}}(\%)$ & VAR (\%) \\
\hline CONTROL & $4.6 \pm 0.8$ & - & 95.0 & $1.1 \pm 0.2$ & - & 95.0 \\
\hline US-750 & $5 \pm 1$ & 24.9 & 95.7 & $1.5 \pm 0.2$ & 41.3 & 97.2 \\
\hline US-1500 & $7.0 \pm 1.1$ & 61.9 & 93.3 & $2.2 \pm 0.3$ & 102.8 & 95.0 \\
\hline
\end{tabular}

515 


\begin{tabular}{|c|c|c|c|c|c|c|}
\hline & \multicolumn{3}{|c|}{ Swelling evolution } & \multicolumn{3}{|c|}{ Hardness evolution } \\
\hline & $\mathrm{TR}_{\mathrm{eq}}$ & $\mathrm{k}_{\mathrm{TR}}\left(10^{-3}\right)\left[\mathrm{min}^{-1}\right]$ & VAR (\%) & $\mathrm{H}_{\mathrm{eq}}(\mathrm{N})$ & $\mathrm{k}_{\mathrm{H}}\left[\mathrm{min}^{-1}\right]$ & VAR $(\%)$ \\
\hline CONTROL & $3.1 \pm 0.2$ & $5.1 \pm 2.1$ & 94.4 & $1.26 \pm 0.08$ & $0.06 \pm 0.02$ & 99.1 \\
\hline US-750 & $4.1 \pm 0.4$ & $5.2 \pm 1.0$ & 92.9 & $1.14 \pm 0.06$ & $0.12 \pm 0.03$ & 99.6 \\
\hline US-1500 & $4.9 \pm 0.4$ & $5 \pm 1$ & 92.7 & $1.15 \pm 0.09$ & $0.17 \pm 0.07$ & 99.2 \\
\hline
\end{tabular}

